Financing constraints for industrial innovation: What do we know?

Dirk Czarnitzki and Hanna Hottenrott

DEPARTMENT OF MANAGERIAL ECONOMICS, STRATEGY AND INNOVATION (MSI) 


\title{
Financing Constraints for Industrial Innovation: What do we know?*
}

\author{
Dirk Czarnitzki ${ }^{\text {a, b, c, d }}$ and Hanna Hottenrott ${ }^{\text {a, b, c }}$ \\ ${ }^{a}$ K.U.Leuven, Dept. of Managerial Economics, Strategy and Innovation \\ ${ }^{b}$ Centre for R\&D Monitoring (ECOOM) at K.U.Leuven \\ ${ }^{c}$ Centre for European Economic Research (ZEW), Mannheim \\ ${ }^{d}$ Centre for Industrial Economics, University of Copenhagen (DK)
}

May 2010

\begin{abstract}
This article provides an overview of the most important insights from economic literature on private investment into research and development activity and how it may be constrained by market failure. The focus is on implications from empirical studies for the identification of financially constrained firms with respect to their innovative activities. The empirical evidence for incentive and financing problems for private sector investment in innovation projects has provided ground for governmental interventions to prevent welfare reducing underinvestment in innovation. However, the survey of the literature shows that designing efficient policy schemes is not straightforward as government funds are scarce, and the impact of financial constraints on investment may differ substantially across firms, types of R\&D projects and the organization of financial markets in different countries.
\end{abstract}

Keywords: Innovation, R\&D, Financial Constraints, Innovation Policy JEL-Classification: O31, O32

Address: Hanna Hottenrott

KU Leuven

Dept. of Managerial Economics, Strategy and Innovation

Naamsestraat 69

3000 Leuven

Belgium

Phone: +3216325 793

E-Mail: hanna.hottenrott@econ.kuleuven.be
Dirk Czarnitzki

KU Leuven

Dept. of Managerial Economics, Strategy and Innovation

Naamsestraat 69

3000 Leuven

Belgium

+3216326906

dirk.czarnitzki@econ.kuleuven.be

* This paper has been written as part of work on the impact of tax incentives on $R \& D$, and supported by the European Commission. We thank Richard Cawley for many helpful comments. 


\section{Introduction}

Innovations typically result from investment in research and development (R\&D). From that perspective, $R \& D$ activities of firms can be seen as private investments in the creation of knowledge. This basic fact makes investment in R\&D projects different from other types of investment.

R\&D activities and resulting innovation constitute an important driver of economic competitiveness and hence sustainable economic growth. As has been illustrated by numerous studies, the impact of $R \& D$ on productivity at the firm level stems from the implementation of newly generated knowledge and technological discoveries into new products, improvement of existing products and production processes or cost reductions of producing existing products or services (see e.g. Stiglitz 1969, Griliches 1980, Schankerman 1981, Griliches and Mairesse 1984, 1990, and Hall and Mairesse 1995). Consequently, $R \& D$ has been recognized as important input factor to industrial production. Potential under-investment may have detrimental effects on competitiveness, on the creation of jobs and on long-run economic performance.

Underinvestment may occur for two main reasons that reduce incentives for private investments in industrial innovation. First, private returns to investment in $R \& D$, that is returns to the company or organization undertaking the investment, are lower than social returns due to knowledge spillovers. Second, capital market imperfections, in particular information asymmetries between the parties involved, may lead to financing constraints for such investment reducing private returns even more. Hence - from a welfare perspective - too little $R \& D$ may be realized in (competitive) markets due to positive externalities and information asymmetries in lending and investing relationships. Both types of market failures are usually regarded as justification for government intervention that aims at promoting $R \& D$ investment.

The following sections provide an overview of the most important insights from economic literature on private investment in innovation and how it may be constrained by market failure. 


\section{Knowledge spillovers and incentives for investment in innovation}

Generally, firms invest in order to realize returns from the investment. In the case of investments in the creation of knowledge the investment may not only provide benefits for the investing firms, but also for third-parties that are able to absorb (parts of) the knowledge that is being created. In a seminal paper, Griliches (1979) outlines the main sources of potential externalities generated by R\&D activities in the form of knowledge spillovers. Knowledge spillovers arise because of the imperfect appropriability of the knowledge imbedded in innovations. In particular, (basic) research projects create knowledge that becomes, at least in part, available to third parties who do not compensate the firm which is conducting and financing these activities.

Thus, firms cannot appropriate the full benefits from its $R \& D$ while it has to bear the entire costs (Nelson 1959, Arrow 1962, Usher 1964). Incentives for investing in R\&D may therefore be reduced and the extent to which private investment in R\&D occurs is lower than socially desirable. The existence of a gap between private and social returns to R\&D has been studied empirically using a range of approaches and measuring methodologies (see Hall 1996, 2002, and Hall and Lerner 2010 for comprehensive surveys of the literature). Knowledge spillovers arise via different routes and can occur voluntarily or involuntarily, e.g. via foreign direct investments, suppliers, customers, and worker mobility (see Cincera and Van Pottelsberghe de la Potterie 2001).

The magnitude of spillovers may vary across industries and by type of R\&D activity. For example, there may naturally be more spillovers in knowledge-intensive industries (see e.g. Saxenien 1990, Acs et al. 1994, Feldman 1994, Henderson et al. 1998).

Spillovers can occur within and across industries. Jaffe (1986) analyzes inter-industry and intra-industry spillovers finding that the latter are stronger. Also a recent paper by Belderbos et al. (2008) explicitly models intra-industry spillovers while previous literature mainly considered inter-industry spillovers. Spence (1984) started the theoretical spillover discussion showing that, on the one hand, R\&D intensity decreases 
in the absence of perfect appropriability of knowledge, but that on the other hand innovation output increases through spillovers.

Cohen and Levinthal $(1989,1990)$ contribute to the spillover debate pointing out the importance of absorptive capacity for identification, assimilation and exploiting knowledge from the environment. The work by Cohen and Levinthal stimulated a debate on the necessary factors of absorptive capacity. Levin and Reiss (1988) show that R\&D outcome increases with spillovers provided firms have complementary knowledge. A major part of the literature has focused on the internalization of knowledge and technology spillovers (Katz 1986, D’Aspremont and Jacquemin 1988, Kamien et al. 1992, see De Bondt 1997 for a survey). One of the key results from this literature is that private incentives to conduct $R \& D$ are reduced (as there is an incentive to free-ride) when R\&D by one firm spills over to other firms. Thus, firms try to maximize incoming spillovers and to minimize outgoing spillovers (Cassiman and Veugelers 2002). One strand of the empirical literature focuses on the question how to measure spillovers and its impact on innovative performance (e.g. Audretsch and Feldman 1996, Lichtenberg and Van Pottelsberghe 1996).

Regarding the type of R\&D, Griliches (1986) points out that (basic) research is a main driver for productivity at the firm level. He shows that expenditures for basic research significantly contribute to productivity growth of U.S. manufacturing firms in the 1970s (also Mansfield 1980). He finds in his cross-sectional analysis that firms that invest a larger fraction of their total R\&D on basic research are more productive, hence stressing the importance of this component. ${ }^{1}$ However, as noted most prominently by Arrow (1962) and Usher (1964) knowledge spillovers may be particularly relevant for the ' $R$ ' component of $\mathrm{R} \& \mathrm{D}$. Thus, (basic) research, which is used as an informational input into subsequent inventive activities, is especially relevant for competitors and other agents that are able to absorb knowledge spillovers. This may reduce incentives to invest in long term research projects and may bring overall industrial research in the economy way below optimal levels.

\footnotetext{
${ }^{1}$ Recently, this finding has been complemented by Czarnitzki et al. (2009) who show that research expenditures exhibit a significant premium over development expenditures with regard to patent productivity in a panel of Belgian firms.
} 
The awareness of the lack of appropriability of returns on investments in knowledge has triggered the establishment of institutional and legal frameworks aimed to protect intellectual property and hence, make appropriability of returns more feasible. However, the fact that neither patents nor secrecy perfectly guarantee the full returns from an innovation suggests an innovation policy that focuses on supporting especially those firms that are expected to create largest spillovers to the economy. Additionally, policies promoting actions that allow internalizing spillovers, such as research joint ventures or other types of collaboration, may help to increase incentives for private R\&D.

Yet, even if full appropriability of returns could be achieved, a second source of potential under-investment, that is, access to financing for such investment, remains important.

\section{Financing Constraints for Innovation}

Like any investment, investments in innovation projects require financial resources. Innovation projects usually involve research and development (R\&D) activities. R\&D, however, is characterized by high, and usually firm specific investment costs on the one hand, and low collateral value, on the other hand. That is, establishing an R\&D program involves significant sunk costs that are an expense and - unlike capital investment cannot be capitalized in the balance sheet. Information asymmetries between investors and managers additionally create uncertainty that affects financing conditions. In principle, there are two sources for financing innovation projects. In particular, external sources such as bank loans or other debt contracts and internal sources, that is retained profits or (new) equity. Firms deciding about their optimal levels of investments will do so while choosing their capital structure in such a way to minimize the long run cost of capital.

Only in a neo-classical world with frictionless markets would the source of financing not matter. The well-known theorem of Modigliani and Miller (1958) showing that investment decisions can be indifferent to capital structure holds for firms in markets where there are no taxes, no bankruptcy costs and no asymmetric information. 
Since the work of Arrow (1962) and Nelson (1959) numerous articles have elaborated on concepts illustrating why the source of financing does matter and in particular matters for investments in the creation of knowledge. These considerations boil down to the recognition that, if capital markets are imperfect and information asymmetries influence lending and investment decisions, the cost of different kinds of capital may vary by type of investment (Meyer and Kuh 1957, Leland and Pyle 1977, Myers and Majluf 1984).

Thus investment in innovation compared to other types of investment is characterized by a high degree of asymmetric information between the parties involved. Complexity and specificity of innovation projects make it difficult for outsiders to judge their potential value. Moreover, firms may be reluctant to reveal details of the projects to potential investors for competition reasons (Stiglitz and Weiss 1981, Greenwald et al. 1984, Bhattacharya and Ritter 1983, Anton and Yao 2002). Lenders or investors may demand a 'premium' on their required rate of return in the sense of Akerlof (1970). If no pursuant rate of return can be appropriated, investors may ration their investment or even refrain from investing at all (Stiglitz 1985). For example Hall (1992), Himmelberg and Petersen (1994) and Czarnitzki and Hottenrott (2009a) show that internal sources of funds are indeed more important for R\&D than for ordinary investment.

In addition to moral hazard problems between the management of a firm and outsiders, such as investors or lenders, information asymmetries between management and owners may impact investment in innovation projects and, hence financing conditions (Jensen and Meckling 1976, Grossman and Hart 1982, Czarnitzki and Kraft 2004).

Besides information asymmetries, the intangibility of the asset that is being created by the investment may make raising funds externally more costly for innovation than for other types of investments. A large fraction of innovation investments, particularly $R \& D$, is sunk and cannot be redeployed (Alderson and Betker 1996). Debt-holders such as banks prefer physical and re-deployable assets as security for their loans, since those can be liquidated in case the project fails or in the event of bankruptcy. Moreover, serving debt requires a stable cash flow which makes financing of innovation projects by external sources more difficult, since most of these projects do not immediately lead to success. In addition, serving debt reduces cash flow for future investments (Hall 1990, Hall 2002). 
There is a whole branch of theoretical and empirical literature illustrating that firms indeed first and foremost use internal funds to finance innovation projects (as compared to debt) indicating a gap in the cost of capital (Leland and Pyle 1977, Bhattacharya and Ritter 1983, Hall 1990, Hall 1992, Himmelberg and Peterson 1994, Bougheas et al. 2003, Czarnitzki and Hottenrott 2009a,b). Consequently, the extent to which financial constraints are binding depends on the firms' ability to raise external or internal funds under the conditions of imperfect capital markets.

\section{Empirical Evidence}

Measuring financial constraints, and identifying firms that are affected, represents a challenge in empirical research. Since the seminal work of Fazzari et al. (1988) econometric studies have tried to detect financial constraints by analyzing investments' sensitivities to changes in available financial resources. This methodology has subsequently been applied to investments in $R \& D$ as such activities constitute an important share of total innovation investments. The conjecture for investment in R\&D was derived accordingly: the more sensitive firms' R\&D investment to cash flow the more binding are financial constraints. Excess sensitivities were regarded as indirectly reflecting firms' lack of access to the credit market.

As an alternative to this indirect approach, recent studies investigate firms' access to external funds more directly through the analysis of standardized credit ratings (Czarnitzki 2006, Czarnitzki and Hottenrott 2009a,b) or credit requests (Piga and Atzeni 2007). The main concern using credit requests, however, relates to a selectivity problem as the most constrained firms which do not expect to get external funding might not even ask for it. Moreover, the increased availability of comprehensive, internationally harmonized survey data on innovation activities at the firm level has enabled researchers to adopt more direct approaches towards the identification of potentially financially constrained firms (Canepa and Stoneman 2002, Tiwari et al. 2007, Savignac 2008, Spielkamp and Rammer 2009). These studies generally define firms as constrained if the firms indicated in a survey that its innovation projects were hampered by the lack of 
finance. One problem that these studies face is the potential endogeneity of the survey indicator. Firms may be more likely to indicate "some" lack of finance, the more innovation projects they conduct and thus the more R\&D they invest. The challenge is to find a valid instrumental variable which is not influenced by the $R \& D$ investment decision of the company, but does influence the survey variable "lack of finance".

As mentioned above, the theoretical literature stresses the role of asymmetric information, moral hazard in borrower-lender relationships, intra-firm organizational structures and other institutional factors that may increase the risk of firms to face financing constraints. Hence, empirical studies - primarily focusing on manufacturing industries - focused on testing hypotheses derived from theoretical considerations. Existing research tackled the questions in multiple dimensions and from different perspectives.

\section{Small and young firms}

Himmelberg and Peterson (1994), Petersen and Rajan (1995), Berger and Udell (2002), Czarnitzki (2006), Ughetto (2008) and Czarnitzki and Hottenrott (2009a) among others analyze the role of firms' age or firms' size in terms of number of employees or assets. The studies by and large find evidence for the hypothesis that smaller firms are more like face financing constraints as they usually cannot provide as much overall collateral value compared to larger, more capital intensive firms. Savignac (2008), for instance, corroborates that the probability of financing constraints decreases with firm size and depends on the firms' ex-ante financing structure. Hyytinen and Toivanen (2005) provide evidence at the industry level for the hypothesis that small and medium sized firms that are dependent on external finance are more likely to fail to conduct innovations projects compared to firms that are less dependent. Hyytinen and Toivanen find that government funding in Finland disproportionately helps firms in industries that are dependent on external financing. This hints to significant capital market imperfections for the former group of firms. 
Moreover, younger firms may be restricted in their R\&D investment due to additional factors that affect financing conditions. Lower equity may increase interest rates required by potential lenders (Müller and Zimmermann 2009). Likewise, problems of asymmetric information may be less severe for older firms that have established a long and stable relationship with their bank. Young firms on the other hand have not yet built such a relationship (Petersen and Rajan 1995, Berger and Udell 2002). Moreover, established firms can innovate by building on their previous innovations, e.g. by product differentiation or improvement, while younger firms need to conduct more fundamental $\mathrm{R} \& \mathrm{D}$ which requires more resources and is much more uncertain. This may aggravate financing constraints since they cannot yet rely on internal funds resulting from cash inflow from former products either. Further, banks may be reluctant to finance innovation projects of young firms because of the 'initial-stage nature' of such projects and the overall higher default risk. This is also found using survey data (Canepa and Stoneman 2002, Savignac 2008, Schneider and Veugelers 2008). Egeln et al. (1997) and Petersen and Rajan (1994, 1995) provide evidence for financing constraints in start-up firms. However, small and young entrepreneurial firms contribute significantly to the introduction of major innovations not only in the US. Such firms tend to innovate more radically, create new technologies, products and markets and often lay ground for further innovations and spur innovation by other firms (Baumol, 2002). Financing constraints that hamper those firms' innovative efforts may thus be particularly harmful for the development of economic competitiveness and hence for sustainable economic growth.

\section{Young innovative firms and innovation capacity}

Recently, the firms' attributes that have been found to trigger financing constraints have been complemented with the firms' innovation profiles. First, the concept of New Technology Based Firms (NTBFs), generally defined as small and medium sized firms in high-tech sectors, has been introduced (Storey and Thether, 1998). Compared to growth rates of start-ups in general, NTBFs were found to grow faster in terms of employment indicating the potential for job-creation embedded in these firms. The slightly different concept of Young Innovative Companies (YICs) takes into account that in addition to the disadvantages of being small and young, these firms exhibit a high R\&D-intensity in the 
sense that funds needs for investment in $R \& D$ are large compared to the funds that the firms generate from their business activities.

Moreover, may such firms find it more difficult to appropriate the returns from their investments in innovations if they lack appropriation strategies (Cassiman and Veugelers 2002) and/or complementary assets (Teece 1986, Gans and Stern 2003).

Additionally, it may be other firms that benefit most from the surplus created by the initial innovation by the YIC through subsequent innovations that build on the knowledge created by the YIC. Hence YICs may bear a high share of the risk of subsequent innovators.

Schneider and Veugelers (2008) find evidence for financing constraints for YICs in Germany using survey data. They show that YICs achieve significantly higher innovative sales than other innovation-active firms, but that access to finance is the most important factor that hampers YICs' innovation activities. Moreover, it does so significantly more than for other innovating firms. The authors also show that existing R\&D subsidy schemes are in general effective, but not for YICs.

Also recently, Hottenrott and Peters (2009) introduce the concept of innovation capability in the discussion on financing constraints. This concept is based on the skill structure of firms' employees, innovation experience and firms' efforts to train their employees and can be applied to broader range of firms than the YICs-concept as it does not exclude firms that are not yet active in $\mathrm{R} \& \mathrm{D}$ and innovation. Using this more general concept on German manufacturing firms, the authors illustrate financial constraints do not depend on the availability of internal funds, size or age per se, but are driven by innovation capability that determines resource requirements. That is, firms with higher innovation capability are more likely to have unexploited innovation projects, independent of their financial background. Firms with high innovation capability but low financial resources turn out to be most likely constrained. Yet, they also observe constraints for financially sound firms. This is striking as innovation capability does not seem to serve as a positive signal to potential lenders and investors. These empirical findings results suggest that if innovation capability is the driving force behind financing constraints governmental action towards innovation policy that aims at supporting private investment in innovation 
activities should focus the factors that form the innovation capability of firms such as the accumulation of human capital.

Such policies may be able to account for the distinctive characteristics of YICs, but would address also firms that are not yet at a stage in which very high R\&D-intensities can be observed. Hence, also those firms may be able to benefit that are not yet very innovative probably due to financing constraints.

\section{Type of $R \& D$}

Until recently, empirical, as well as theoretical literature has paid little attention to the fact that R\&D projects can differ substantially in terms of uncertainty of returns, resource requirements, risk of failure, involvement of basic research, the importance of secrecy and that these properties may affect financing conditions. Additionally, most articles, surveys, evaluations and reports concerning allocation of resources to R\&D do not explicitly distinguish between the different components of $R \& D$, namely research and development oriented projects. However, characteristics usually attributed to $R \& D$ activities in general, such as intangibility and outcome uncertainty are very likely to be more applicable for ' $R$ ' compared to ' $D$ '. Research projects are also usually characterized by being "far from the market” and may induce higher externalities decreasing the likelihood of profitability. Moreover, development takes place at a much later stage of the R\&D process building on previously generated knowledge.

An exception on the first issue is Kamien and Schwartz (1978) who, in a theoretical model, distinguish firms who are doing routine R\&D to strengthen their established product lines and firms investing in more fundamental $R \& D$ projects aiming at more radical innovations. According to this distinction, the former firms are less likely to face financial constraints on their activities than the latter firms. Since fundamental innovations usually involve basic research, require significantly more resources, are much riskier in terms of default and expected returns, and are more prone to secrecy issues, the acquisition of external capital may be curtailed. 
Czarnitzki and Hottenrott (2009b) test this empirically by investigating R\&D investments of product innovators where the type of $R \& D$, with respect to the degree of innovativeness, is considered as being decisive for financial constraints. They show that firms pursuing cutting-edge $R \& D$ strategies are indeed subject to financial constraints in the credit market. $R \& D$ spending turns out to be curtailed for cutting-edge $R \& D$ while it is not for routine R\&D investment. Also Lindholm et al. (2000) stress the role of public support particularly for fundamental innovation.

A further study by Czarnitzki et al. (2009) explicitly takes into account the heterogeneity of the two components of R\&D. By compartmentalizing industrial R\&D activity into its components, they argue that financing development ' $\mathrm{D}$ ' externally should be less critical than it is for industrial research ' $R$ '. The empirical study, indeed, reveals that ' $R$ ' investment is more sensitive to the firms' operating liquidity than ' $\mathrm{D}$ ' indicating that firms have to rely even more on internal funds for financing their research compared to development activities. Looking at aggregated $R \& D$ expenditures of the firm would not have revealed this effect. Moreover, they find that (basic) research subsidy recipients invest more into ' $R$ ' than other firms, and that their investment is also less sensitive to internal liquidity.

These findings have interesting consequences for policy. As cutting-edge innovations are generally regarded as the driving forces of technological progress and also yield higher social returns than routine $R \& D$ projects in the long run, this may call for policy measures towards cutting-edge R\&D projects. Second, research-oriented projects may require distinct attention implying that a uniform $R \& D$ policy may not be able to alleviate constraints to a sufficient extent. Hence, calling for different policy support schemes for 'R' and ' $\mathrm{D}$ '.

\section{Financial Market Regimes}

Hall (1992), Himmelberg and Peterson (1994), Bhagat and Welch (1995), Hall et al. (1999), Mulkay et al 2001, Bond et al. (2006) study the role of financial market regimes. Hall (1992) and Himmelberg and Peterson (1994) find a positive relationship between R\&D activity and cash-flow for US firms. Mulkay et al. (2001) show that cash flow 
seems to be more important for any type of investment in the US than in France. Bond et al. (2006) find that cash flow determines whether UK firms do R\&D, but not how much, while they do not find such a relationship for Germany. In contrast, Harhoff (1998) confirms a positive sensitivity to cash-flow for German manufacturing firms. In a similar vein, a negative association between debt and $R \& D$ activity was reported for US but not for Japanese firms by Bhagat and Welch (1995). For US and UK firms they observe a positive correlation between stock return and R\&D activity two years later. Bougheas et al. (2003) find similar results for Ireland. Canepa and Stoneman (2002) compare intercountry differences in Europe based on survey information and find a higher perceived importance of financing constraints on innovation for firms' for smaller firms in marketbased systems.

\section{Conclusion and final remarks}

A number of conclusions can be drawn of from this body of empirical literature. On the one hand, there is evidence that internal funds are a crucial source of financing for innovation. How much a firm has to rely exclusively on internal funds because credit is constrained depends on firm and project characteristics.

Moreover, macro factors such as the financial market system play a crucial role. Firms in so-called Anglo-Saxon 'market-based' economies with developed and liquid stock markets generally rely to a lesser extent on bank financing per-se compared to 'bankingdominated' financial systems that can for example be found in continental Europe. Such findings indicate that even in a globalized world financing constraints differ in their nature and call for different solutions depending on the financial market environment faced by firms.

Not surprisingly private sector initiatives towards a solution for closing the funding gap for young firms and start-ups have been observed in Anglo-Saxon economies. Most

prominently, the emergence and growth of the Venture Capital (VC) industry can be seen as an attempt for closing the financing gap by reducing asymmetric information and moral hazard rather than simply subsidizing the investment (see for example Chan 1983, 
Lerner 1994a,b, 1995, 1998, Berglöf 1994, Hellmann 1998, Cornelli and Yosha 2003, Kaplan and Strömberg 2003 and Hall and Lerner 2010 for a recent survey). Gompers (1995), for example, shows that VC firms invest in early-stage companies and in hightechnology industries where informational asymmetries are significant and monitoring is valuable.

Continental European economies have not witnessed a significant growth in the provision of VC. VC financing in most continental European countries is still rare and focused on some few (high-tech) industries, e.g. bio-tech. A recent study by Breuer et al. (2007) finds substantial differences between the German and the US VC markets. They suggest legal differences as well as cultural differences may cause the comparative underdevelopment of the German VC industry and the difference in the importance of debt financing (see also for example Mayer 1988, Bebenroth et al. 2009, Deutsche Bundesbank 2000).

However, the VC solution to the problem of financing innovation is not only limited geographically, but also intrinsically. First, it focuses only on a few sectors at a time and often does not apply to small start-up investments. Second, for the VC solution to work VC firms must be given the opportunity to exit the investment at a certain point. This, however, requires well developed stock markets (see Bottazzi and Da Rin 2002 and Hall and Lerner 2010).

These limitations may also be the reason why public policy support programs for new and young firms have been established in US as well as in other market-based economies. The empirical evidence for incentive and financing problems for private sector investment in innovation projects has thus provided ground for governmental interventions to prevent welfare reducing underinvestment in innovation. Such policy actions include the protection of intellectual property, direct financial support of $R \& D$ and tax incentives for $R \& D$ as well as the encouragement of $R \& D$ collaboration and partnerships between firms and between science and industry. However, the results also show that designing efficient policy schemes is not straightforward as government funds are limited and support should hence be addressed to firms which are really constrained. 
Given that even independently of any financial crisis, economic theory and empirical evidence stresses the existence of financing constraints, the problem presumably deteriorates as the current financial crisis will require banks to conduct an even more detailed risk assessment in the future. Ughetto (2007) addresses how systematic risk assessment techniques within the implementation of the New Basle Capital Accord affect financing of innovation, in particular the screening of innovative firms. As intangible investments like R\&D are not reflected in the firms' balance sheets, financial statementbased estimations of firm value and creditworthiness (internal, but also external ratings) may penalize firms that invest in R\&D at least in the short-run. ${ }^{2}$

Thus, both politics and industry fear the deterioration of firms' financing conditions for such activities as forward-looking innovation projects.

This calls for targeted policy support directed at most constrained firms and those projects that are likely to face the largest gab between private and social returns. Several empirical studies have shown that for example public R\&D subsidies may indeed work quite well as they do not crowd out private investment in $R \& D$, but lead to additional investments and additional innovation outcome (e.g. David et al., 2000, Almus and Czarnitzki 2003, Aerts and Czarnitzki 2006, Czarnitzki and Hussinger 2004, Czarnitzki and Licht 2006, Czarnitzki et al. 2007, Hussinger 2008).

However, for any policy programs to be effective it appears to be crucial to not rely on a uniform R\&D and innovation support policy, but to provide nuanced programs that address particular kinds of firms in particular ways. Based on the theoretical considerations and empirical evidence presented above, several target groups at the firm and project level can be identified. First, these groups turned out to be most likely to be constrained. Second, the detrimental and welfare reducing effects of foregone

\footnotetext{
${ }^{2}$ Ughetto (2007) finds that even if qualitative factors do as well affect the credit rating, these are usually not directly related to innovation. However, she also points out that some of the Italian banks in her sample have established loan schemes directed at 'technology-based activities' that apply special conditions in terms of interest and collateral requirements. However, the latter type of loans requires screening of external expert committees. It therefore remains to be evaluated how beneficial granting such loans is for these banks. See Czarnitzki and Kraft (2007) for potential consequences of the Basle II capital accord on financing investments, in general, and Czarnitzki and Kraft (2006) for short-run (negative) effects of R\&D on firms' credit ratings.
} 
investments by these firms are likely to be considerable. These groups do not exclude each other. Firms may fit into one or several categories.

$>$ Small (and medium-sized) firms

$>$ Young and start-up firms and firms with high innovation capability

> Research projects or more fundamental R\&D compared to development projects or routine $\mathrm{R} \& \mathrm{D}$

Firms in financial market regimes that may hamper a working VC market

How the financial crisis has impacted the financing conditions of innovation will provide a starting point for future research. In addition, the rigorous evaluation of existing policy schemes addressing financial constraints for the above mentioned groups of firms or type of investment appears to be a desirable task for (European) innovation policy. 


\section{References}

Acs, Z., Audretsch, D.B. and M.P. Feldman (1994), R\&D Spillovers and Recipient Firm Size, Review of Economics and Statistics, 76(2), 336-40.

Aerts, K. and D. Czarnitzki (2006), The Impact of Public R\&D-Funding in Flanders, Brussels, Belgium: IWT Study No. 54.

Akerlof, G. A. (1970), The market for 'Lemons': Quality, Uncertainty, and the Market Mechanism, Quarterly Journal of Economics 84, 488-500.

Alderson, M. and B. Betker (1996), Liquidation Costs and Accounting Data, Financial Management 25(2), 25-36.

Almus, M. and D. Czarnitzki (2003), The Effects of Public R\&D Subsidies on Firms' Innovation Activities: The Case of East Germany, Journal of Business and Economic Statistics 21(2), 226-236.

Anton, J. and D. Yao (2002), The Sale of Ideas: Strategic Disclosure, Property Rights, and Contracting, Review of Economic Studies 69(3), 513-531.

Arrow, K. (1962), Economic Welfare and the Allocation of Resources for Invention, in: Nelson, R. (Ed.), The Rate and Direction of Inventive Activity.

Audretsch, D.B. and M.P. Feldman (1996), R\&D Spillovers and the Geography of Innovation and Production, American Economic Review 86, 630-640.

Baumol (2002), The Free-Market Innovation Machine, Princeton University Press.

Bhagat, S. and I. Welch (1995), Corporate Research \& Development Investments International Comparisons, Journal of Accounting and Economics 19, 443-470.

Bebenroth, R., Vollmer, U. and D. Dietrich (2009), Bank Regulation and Supervision in Bank-Dominated Financial Systems: a Comparison between Japan and Germany, European Journal of Law and Economics 27, 177-209.

Belderbos, R., Lykogianni, E. and R. Veugelers (2008), Strategic R\&D location by multinational firms: Spillovers, technology sourcing, and competition spillovers, Journal of Economics and Management Strategy 17(3), 759 - 779.

Berger, A. and G. Udell (2002), Small Business Credit Availability and Relationship Lending: The Importance of Bank Organizational Structure, Economic Journal 112, 32-53.

Berglöf, E. (1994), A control theory of venture capital finance, Journal of Law, Economics, and Organizations 10, 247-67.

Bhattacharya, S. and J. Ritter (1983), Innovation and Communication: Signaling with Partial Disclosure, Review of Economic Studies 50(2), 331-346.

Bond, S., Harhoff, D. and J. Van Reenen (2006), Investment, R\&D and Financial Constraints in Britain and Germany, Annales d'Économie et de Statistique, forthcoming. 
Bougheas, S., Görg, H. and E. Strobl (2003), Is R\&D Financially Constrained? Theory and Evidence from Irish Manufacturing, Review of Industrial Organization 22(2), 159-174.

Bottazzi, L. and M. Da Rin (2002), Venture Capital in Europe and the Financing of Innovative Companies, Economic Policy 17(34), 231-269.

Breuer, W., Antonczyk, R. C. and Brettel, M. (2007), Venture Capital Financing in Germany - The Role of Contractual Arrangements in Mitigating Incentive Conflicts, mimeo.

Canepa, A. and P. Stoneman (2002), Financial Constraints on Innovation: A European Cross-Country Study, University of Warwick, EIFC - Technology and Finance Working Papers 011.

Cassiman, B. and R. Veugelers (2002), R\&D cooperation and spillovers: some empirical evidence from Belgium, American Economic Review 92(4), 1169 - 1184.

Chan, Y. (1983), On the positive role of financial intermediation in allocation of venture capital in a market with imperfect information, Journal of Finance 38, 1543-1568.

Cohen, W.M. and D.A. Levinthal (1989), Innovation and learning: The two faces of R\&D: Implications for analysis of R\&D investment. Economic Journal 99(397), 569-596.

Cohen, W.M. and D.A. Levinthal (1990), Absorptive capacity: A new perspective on learning and innovation, Administrative Science Quarterly 35, 128-152.

Cornelli, F. and O. Yosha (2003), Stage financing and the role of convertible debt, Review of Economic Studies 70, 1-32.

Cincera, M. and B. van Pottelsberghe de la Potterie (2001), International R\&D Spillovers: a Survey, Brussels Economic Review/Cahiers Economiques de Bruxelles 169, 3-31.

Czarnitzki, D. (2006), Research and Development in Small- and Medium-Sized Enterprises: The Role of Financial Constraints and Public Funding, Scottish Journal of Political Economy 53(3), 257-335.

Czarnitzki, D., B. Ebersberger and A. Fier (2007), The Relationship between R\&D Collaboration, Subsidies and R\&D performance: Empirical Evidence from Finland and Germany, Journal of Applied Econometrics 22(7), 1347-1366.

Czarnitzki, D. and H. Hottenrott (2009a), R\&D Investment and Financing Constraints of Small and Medium-Sized Firms, Small Business Economics, forthcoming.

Czarnitzki, D. and H. Hottenrott (2009b), Financial Constraints: Routine versus CuttingEdge R\&D Investment, Journal of Economics and Management Strategy, forthcoming.

Czarnitzki, D., H. Hottenrott and S. Thorwarth (2009), Industrial Research versus Development Investment: The Implications of Financial Constraints, ZEW Discussion Paper No. 09-049, Mannheim. 
Czarnitzki, D. and K. Hussinger (2004), The Link Between R\&D Subsidies, R\&D Spending, and Technological Performance, ZEW Discussion Paper No. 04-56, Mannheim.

Czarnitzki, D. and K. Kraft (2004), Management control and innovative activity, Review of Industrial Organization 24(1), 1-24.

Czarnitzki, D. and K. Kraft (2006), R\&D and Firm Performance in a Transition Economy, Kyklos 59, 481-496.

Czarnitzki, D. and K. Kraft (2007), Are Credit Ratings Valuable Information?, Applied Financial Economics 17(13), 1061-1070.

Czarnitzki, D., K. Kraft and S. Thorwarth (2009), The Knowledge Production of 'R' and 'D', Economics Letters 105, 141-143.

Czarnitzki, D. and G. Licht (2006), Additionality of Public R\&D Grants in a Transition Economy: The Case of Eastern Germany, Economics of Transition 14(1), 101-131.

D'Aspremont, C. and A. Jacquemin (1988), Cooperative and noncooperative R\&D in duopoly with spillovers, American Economic Review 78, 1133-1137.

David, P.A., B.H. Hall and A.A. Toole (2000), Is public R\&D a complement or substitute for private R\&D? A review of the econometric evidence, Research Policy 29, 497529.

De Bondt, R. (1997), Spillovers and innovative activities, International Journal of Industrial Organization 15(1), 1-28.

Deutsche Bundesbank (2000), The market for venture capital in Germany, Monthly Report October 2000, Available at http://www.bundesbank.de/download/volkswirtschaft/mba/2000/200010mba_art01 _venturecapital.pdf.

Egeln, J., Licht, G. und Steil, F. (1997), Firm Foundations and the Role of Financial Contraints, Small Business Economics 9, 137-150.

Fazzari, S., Hubbard, R. and B.C. Petersen (1988), Financing Constraints and Corporate Investment, Brookings Papers on Economic Activity 1, 141-206.

Feldman, M.P. (1994), The Geography of Innovation, Dordrecht: Kluwer Academic.

Gans, J. and S. Stern (2003), When Does Funding Research by Smaller Firms Bear Fruit?: Evidence from the SBIR, Economics of Innovation and New Technology 12(4), 361-384.

Gompers, P. (1995), Optimal investment, monitoring, and the staging of venture capital, Journal of Finance 50, 1461-89.

Greenwald, B., J. Stiglitz, and A. Weiss (1984), Information Imperfections and Macroeconomic Fluctuations, American Economic Review 74, 194-199.

Griliches, Z. (1979), Issues in Assessing the Contribution of Research and Development to Productivity Growth, Bell Journal of Economics 10(1), 92-116. 
Griliches, Z. (1980), R\&D and the Productivity Slowdown, American Economic Review 70, 343-348.

Griliches, Z. and J. Mairesse (1984), Productivity and R\&D at the Firm Level, in: Z. Griliches (ed.), R\&D, Patents, and Productivity. Chicago: University of Chicago Press.

Griliches, Z. (1986), Productivity, R and D, and Basic Research at the Firm Level in the 1970’s, American Economic Review 76(1), 141-154.

Griliches, Z. and J. Mairesse (1990), $R \& D$ and Productivity Growth: Comparing Japanese and U.S. Manufacturing Firms, in: C. Hulten (ed.), Productivity Growth in Japan and the United States, Chicago: University of Chicago Press.

Grossman, S. and O. Hart (1982), Corporate Financial Structure and Managerial Incentives, in: McCall, J. (Ed.), The Economics of Information and Uncertainty.

Hall, B. (1990), The Impact of Corporate Restructuring on Industrial Research and Development, Brooking Papers on Economic Activity 1, 85-136.

Hall, B. (1992), Investment and Research and Development at the Firm Level: Does the Source of Financing Matter?, NBERWorking Paper 4096.

Hall, B. (1996), The Private and Social Returns to Research and Development, in: Smith, B. \& C. Barffeld (Eds.), Technology, R\&D, and the Economy.

Hall, B. (2002), The Financing of Research and Development, Oxford Review of Economic Policy 18(1), 35-51.

Hall, B.H. and J. Lerner (2010), The Financing of R\&D and Innovation, in Hall, B. H. and N. Rosenberg (eds.), Handbook of the Economics of Innovation, Version August 2009, Elsevier-North Holland.

Hall, B.H., and J. Mairesse (1995), Exploring the Relationship Between R\&D and Productivity in French Manufacturing Firms, Journal of Econometrics 65, 263-293.

Hall, B.H., Mairesse, J., Branstetter, L. and B. Crepon (1999), Does Cash Flow Cause Investment and R\&D: An Exploration Using Panel Data for French, Japanese, and United States Scientific Firms, in Audretsch, D., and A. R. Thurik (eds.), Innovation, Industry Evolution, and Employment, Cambridge, England: Cambridge University Press.

Harhoff, D. (1998), Are There Financing Constraints for R\&D and Investment in German Manufacturing Firms?, Annales d'Economie et de Statistique, 49/50, 421-456.

Hellmann, T. (1998), The allocation of control rights in venture capital contracts, RAND Journal of Economics 29, 57-76.

Henderson, R., Jaffe, A. and M. Trajtenberg (1998), Universities as a source of commercial technology: a detailed analysis of university patenting 1965-1988, Review of Economics and Statistics 65, 119-127.

Himmelberg, C. and B. Peterson (1994), R\&D and Internal Finance: A Panel Study of Small Firms in High-Tech Industries, Review of Economics and Statistics 76, 3851. 
Hottenrott, H. and Peters, B. (2009), More Money, More Innovation? Innovation Capacity and Financing Constraints for Innovation, mimeo, Leuven, Mannheim.

Hussinger, K. (2008), R\&D and Subsidies at the Firm Level: An Application of Parametric and Semi-Parametric Two-Step Selection Models, Journal of Applied Econometrics 23, 729-747.

Hyytinen, A. and Toivanen, O. (2005), Do financial constraints hold back innovation and growth? Evidence on the role of public policy, Research Policy 34, 1385-1403.

Jaffe, A.B. (1986), Technological Opportunity and Spillovers of R\&D: Evidence from Firms' Patents, Profits, and Market Value, American Economic Review 76(5), 9841001.

Jensen, M. and W. Meckling (1976), The Theory of the Firm: Managerial Behavior, Agency Cost, and Ownership Structure, Journal of Financial Economics 3, 305360.

Kamien, M.I. and N.L. Schwartz (1978), Self-Financing of an R\&D Project, The American Economic Review 68, 252-261.

Kamien, M.I., Muller, E. and I. Zang (1992), Research Joint Ventures and R\&D Cartels, American Economic Review 82(5), 1293-1306.

Kaplan, L. and P. Strömberg (2003), Financial contract theory meets the real world: an empirical analysis of venture capital contracts, Review of Economic Studies 70, 281-315.

Katz, M.L. (1986), An analysis of cooperative research and development, Rand Journal of Economics 17(4), 527-543.

Leland, H. and D. Pyle (1977), Informational Asymmetries, Financial Structure, and Financial Intermediation, Journal of Finance 32, 371-387.

Lerner, J. (1994b), Venture capitalists and the decision to go public, Journal of Financial Economics 35, 293-316.

Lerner, J. (1994a), The syndication of venture capital investments, Financial Management 23, 16-27.

Lerner, J. (1995), Venture capitalists and the oversight of private firms, Journal of Finance 50, 301-18.

Lerner, J. (1998), 'Angel' Financing and Public Policy: An Overview, Journal of Banking and Finance 22, 773-783.

Levin, R.C., Reiss, P.C. (1988), Cost-reducing and demand-creating R\&D with spillovers, Rand Journal of Economics 19(4),403-431.

Lichtenberg, F.R. and van Pottelsberghe de la Potterie, B. (1996), International R\&D spillovers: A reexamination, NBER Working Paper Series \# 5668.

Mansfield, E. (1980), Basic research and productivity increase in manufacturing, American Economic Review 70, 863-873. 
Mayer, C., 1988, “New Issues in Corporate Finance”, European Economic Review, 32, 1167-1183.

Meyer, J. R. and E. Kuh (1957), The Investment Decision: An Empirical Study, Cambridge.

Modigliani, F. and M. Miller (1958), The Cost of Capital, Corporation Finance and the Theory of Investment, American Economic Review 48, 261-297.

Müller, E. and V. Zimmermann (2009), The Importance of Equity Finance for R\&D Activity - Are There Differences Between Young and Old Companies?, Small Business Economics 33(3), 303-318.

Mulkay, B., B.H. Hall and J. Mairesse (2001), Investment and R\&D in France and in the United States, Deutsche Bundesbank, ed., Investing Today for the World of Tomorrow, Springer.

Myers, S. and N. Majluf (1984), Corporate Financing and Investment Decisions When Firms Have Information that Investors Do Not, Journal of Financial Economics 13, 187-221.

Nelson, R. (1959), The Simple Economics of Basic Scientific Research, Journal of Political Economy 49, 297-306.

Peterson, M. and R. Rajan (1994), The Benefits of Lending Relationships: Evidence from Small Business Data, Journal of Finance 49, 3-37.

Petersen, M. and R. Rajan (1995), The Effect of Credit Market Competition on Lending Relationships: Evidence from Small Business Data, Journal of Finance 49, 3-37.

Piga, C. and G. Atzeni (2007), R\&D Investment, Credit Rationing and Sample Selection, Bulletin of Economic Research 59(2), 149-178.

Savignac, F. (2008), Impact of Financial Constraints on Innovation: What Can Be Learned from a Direct Measure?, Economics of Innovation and New Technology 17(6), 553-569.

Saxenian, A.L. (1990) Regional Networks and the Resurgence of Silicon Valley, California Management Review 33, 89-111.

Schankerman, M. (1981), The Effects of Double-Counting and Expensing on the Measured Returns to R\&D, Review of Economics and Statistics 63(3), 454-458.

Schneider, C. and R. Veugelers (2008), On Young Innovative Companies: Why They Matter and How (not) to Policy Support Them, mimeo, Copenhagen, Leuven.

Spence, M. (1984), Cost Reduction, Competition, and Industry Performance, Econometrica 52(1), 101-121.

Spielkamp, A. and Rammer, C. (2009), Financing of Innovation - Thresholds and Options, Management \& Marketing 4(2), 3-18.

Stiglitz, J. (1969), Theory of Innovation - Discussion, American Economic Review 59, 44-46. 
Stiglitz, J. (1985), Credit Markets and the Control of Capital, Journal of Money, Credit and Banking 17, 393-410.

Stiglitz, J. and A. Weiss (1981), Credit rationing in markets with imperfect information, American Economic Review 71, 393-410.

Storey, D.J. and B.S. Tether (1998), New technology-based firms in the European Union: an introduction, Research Policy 26, 933-946.

Teece, D. (1986), Profiting from Technological Innovation, Research Policy 15(6), 285305.

Tiwari, A., P. Mohnen, F. Palm, and S. Schim van der Loeff (2007), Financial Constraint and R\&D Investment: Evidence from CIS, United Nations University, Maastricht Economic and Social Research and Training Centre on Innovation and Technology, UNU-MERIT Working Paper Series 011.

Ughetto, E. (2007), The financing of innovative activities by banking institutions: policy issues and regulatory options, Innovation Studies Working Paper, No. 02/2007, Torino, Italy.

Ughetto, E. (2008), Does internal finance matter for R\&D? New evidence from a panel of Italian firms, Cambridge Journal of Economics 32(6), 907-925.

Usher, D. (1964), The Welfare Economics of Innovation, Econometrica 31, 279-287. 